\title{
Hudleger vil helst bo i Oslo
}

\author{
De fleste nyutdannede hudleger fra Oslo universitetssykehus velger å forbli i hovedstaden etter endt spesiali- \\ sering. Nesten ingen søker seg til avtalepraksis utenfor Oslo-området. Norsk dermatologi har et distriktspro- \\ blem som kan bli forsterket med innføringen av faste utdanningsstillinger. Spesialistutdanningen må tilpasses \\ nye tider.
}

Praktisk talt all utdanning av spesialister i hud- og veneriske sykdommer i Norge skjer ved landets fem universitetssykehus, som har 32 av 35 utdanningsstillinger i faget (data fra spesialitetskomiteen). Seksjon for hudsykdommer ved Oslo universitetssykehus er landets største hudavdeling og den eneste i Helse Sør-Øst. Rekrutteringen til avtalepraksis og overlegestillinger utenfor de store byene er svak, særlig på Østlandet og i Nord-Norge.

I de fleste andre kliniske spesialiteter starter mange leger sin spesialistutdanning ved et lite eller mellomstort sykehus, for så å tjenestegjøre i en tidsbegrenset periode ved et universitetssykehus. Eksempelvis er 15 av 19 utdanningsavdelinger i øre-nesehals-faget og 15 av 20 utdanningsavdelinger i øyefaget ved små og mellomstore sykehus (1). I hudfaget er kun tre av åtte utdanningsavdelinger ved slike sykehus, alle med én utdanningsstilling hver. Derfor starter nesten alle hudleger sin spesialistutdanning ved et universitetssykehus.

Antall privatpraktiserende hudleger er omtrent det samme som antall overleger ved hudavdelinger i offentlige sykehus (egne data). Utdanningsavdelingene skal med andre ord utdanne hudleger både til privatpraksis og til overlegestillinger. Dette ser ut til å være glemt i premissene for avtalen om faste utdanningsstillinger, der leger kan velge å forbli i samme stilling etter at de har fătt sin spesialitet «frem til de (etter søknad) får tilbud om en overlegestilling», slik daværende legepresident i sin tid skrev i Tidsskriftet (2).

Mange hudleger er derfor bekymret for følgene av innføringen av utdanningsstillinger med ubegrenset ansettelsestid ved norske sykehus (3). Hvordan vil faste utdanningsstillinger påvirke rekrutteringen til avtalepraksis og til overlegestillinger utenfor de store byene? Hvilke følger vil det få for utdanningskapasiteten? Noen vil mene at dette er usikkert. Vi mener at erfaringer fra Helse SørØst de siste årene kan gi en sterk pekepinn om hvordan det vil gå. Oftest er jo nær fortid den beste prediktor for nær fremtid.

\section{Unge hudleger ønsker å bo i Oslo}

For å kartlegge karrierevalg og bopreferanser til dem som de siste årene er godkjent som spesialist i hud- og veneriske sykdommer, har vi innhentet data fra Legeforeningens sekretariat, Oslo universitetssykehus og Helse Sør-Øst.

I tiårsperioden 2007-16 ble 63 leger god- kjent som spesialist i hud- og veneriske sykdommer etter norske regler (Anders Taraldset, Legeforeningen, personlig meddelelse), hvorav 24 på grunnlag av tjeneste ved Oslo universitetssykehus. I dag arbeider 19 av disse 24 fortsatt i Oslo-området, hvorav åtte $i$ helprivat praksis (egne data) (tab 1).

I perioden 2008-16 utlyste Helse Sør-Øst 15 praksisavtaler utenfor Oslo-området, bl.a.

\section{«Vi er i ferd med å få et todelt arbeidsmarked for hudleger - ett i de store byene for dem med spesialist- utdanning fra Norge og ett i distriktene for leger med spesialistut- danning fra utlandet»}

i byer som Lillehammer, Kristiansand, Larvik og Sarpsborg. 12 av disse 15 er i dag besatt av leger med spesialisering fra utlandet eller andre helseregioner eller er uten norske søkere (data fra Helse Sør-Øst) (tab 2).

Disse tallene viser med all tydelighet at de fleste hudleger med spesialisering fra Oslo universitetssykehus velger å forbli i Oslo-området etter godkjenning som spesialist fremfor å søke seg til avtalepraksis $i$ andre deler av landet. Ingen kan bebreide dem for dette - i Oslo har de slått rot, ofte med hus, ektefelle, barn, kjent nærmiljø og tett omgangskrets. Ønsket om å forbli i byen er derfor sterkt. Samtidig er det slik at de fleste praksisavtaler utenfor Osloområdet søkes og blir tildelt spesialister fra utlandet eller fra andre helseregioner. Vi er $i$ ferd med å få et todelt arbeidsmarked for hudleger - ett i de store byene for dem med spesialistutdanning fra Norge og ett i distriktene for leger med spesialistutdanning fra utlandet.

Mye tyder på at denne utviklingen vil fortsette. Oslo universitetssykehus vil ikke ha nok overlegestillinger til alle nye hudspesialister som utdannes der. For mange av disse vil det være faglig og sosialt mer attraktivt å forbli i sin utdanningsstilling som legespesialist fremfor å gå ut i avtalepraksis i andre deler av landet eller i helprivat praksis uten trygderefusjon i Oslo-området (3). Dette vil ha som konsekvens at disse stillingene vil være blokkert og ikke kan brukes til å utdanne nye hudleger. Dermed vil utdanningskapasiteten gå ned, unge leger som ønsker å bli hudlege vil få det vanskeligere med å komme inn i et spesialiseringsløp, og rekrutteringen til avtalehjemler og overlegestillinger utenom de store byene vil svekkes ytterligere. I en slik situasjon vil sykehuset bryte sin lovpålagte plikt til å «sørge for at regionens behov for utdanning av spesialister blir dekket», slik det er formulert i spesialistforskriftens $\S 4$, hjemlet i lov om spesialisthelsetjenesten (4). Avdelingslederne vil komme til å måtte velge mellom å følge norsk lov eller å oppfylle arbeidsavtaler.

Forholdene i de andre helseregionene er ikke særlig bedre. I Nord-Norge er det for tiden mange utlyste avtalehjemler for privat hudlegepraksis og overlegestillinger uten søkere (Dagfinn Moseng, Universitetssykehuset Nord-Norge, personlig meddelelse).

Fagmiljøene har de siste årene arbeidet aktivt for å styrke spesialistutdanningen i hud- og veneriske sykdommer, bl.a. med nye læringsmål og etablering av nordiske kurs. Norsk dermatologisk forskning er i fremgang, og det avlegges flere dermatologiske doktorgrader enn noen gang. For å styrke forskningen ved egen avdeling vil antagelig avdelingsledere i mange tilfeller foretrekke søkere med forskningskompetanse ved ansettelse i ledige utdanningsstillinger. Dette kan ytterligere svekke rekrutteringen av leger som kunne tenke seg å gå over i ordinær klinisk praksis utenfor universitetsbyene etter godkjent spesialistutdanning. Avdelingsledere kan bli rausere med permisjonssøknader og la være å forlenge enkelte vikariater, noe som vil innebære flere vikariater enn til nå.

\section{Hva kan gjøres?}

Norsk forening for dermatologi og venerologi har hatt flere møter med både arbeidsgiversiden, Legeforeningen sentralt og styret i Praktiserende spesialisters landsforening (PSL) om denne saken og diskutert mulige tiltak. Disse omfatter bl.a. flere gjennomstrømningsstillinger (dvs. utdanningsstillinger med tidsbegrensning), opprettelse av flere små hudavdelinger og kobling av enkelte utdanningsstillinger til avtalehjemler 
Tabell 1 Nåværende arbeidssted for leger godkjent som spesialist i hud- og veneriske sykdommer 2007-16 basert på tjeneste ved Oslo universitetssykehus ( $\mathrm{n}=24)$ (egne data)

\begin{tabular}{lc} 
Oslo og Akershus & 19 \\
Oslo universitetssykehus & 10 \\
Helprivat praksis & 8 \\
Avtalepraksis & 1 \\
Utenfor Oslo og Akershus & 5 \\
Helprivat praksis ${ }^{1}$ & 3 \\
Avtalepraksis & 1 \\
Utlandet & 1 \\
\hline
\end{tabular}

${ }^{1}$ Inkludert ett deltidsvikariat i avtalepraksis

Tabell 2 Praksisavtaler i Helse Sør-Øst utenfor Oslo og Akershus utlyst i perioden 2008-16 (n = 15) (data fra Helse Sør-Øst)

$\begin{array}{ll}\text { Hudleger fra utlandet } & 6 \\ \text { Hudleger fra andre helseregioner } & 3 \\ \begin{array}{l}\text { Hudleger fra Oslo universitets- } \\ \text { sykehus }\end{array} & 3 \\ \text { Ubesatt uten søkere } & 2 \\ \text { Ubesatt uten norske søkere } & 1\end{array}$

og overlegestillinger, slik Johan Torgersen, daværende leder i Yngre legers forening, foreslo i 2014 (møtereferat 4.12. 2014).

Vår erfaring fra disse møtene er at mange har vanskelig for å ta innover seg hvor kritisk situasjonen kan bli for hudfaget, og at viljen og evnen til å vurdere mulige mottiltak på en seriøs måte er sterkt varierende. $\mathrm{Vi}$ overdriver, sies det gjerne, ofte uten at man gidder å sette seg inn i saken. Muligheten for å opprette hudavdelinger ved små og mellomstore sykehus er begrenset, og det blir neppe lettere å rekruttere hudleger til overlegestillinger ved slike avdelinger enn det har vært å rekruttere hudleger til avtalepraksis. Norsk dermatologi trenger hudavdelinger av en viss størrelse for å løfte seg faglig og vitenskapelig, og dagens avdelinger er i internasjonal sammenheng små.

\section{Grove feil i legestillingsregisteret}

Vi er også overrasket og skuffet over at Helsedirektoratets rapport fra november 2016 om leger i primær- og spesialisthelsetjenesten ikke har tatt med hud- og veneriske sykdommer på listen over spesialiteter som bør ha særskilt «strategisk oppmerksomhet» fremover $(5,6)$. Vi tror dette skyldes grove feil i legestillingsregisteret i Helsedirektoratet, der antall utdanningsstillinger i hudfaget er oppgitt å være 60,8 totalt, inkludert 27,3 ved Oslo universitetssykehus (7). Våre tall, basert på nær kjennskap til realitetene, er henholdsvis 35 og 13, altså rundt det halve. Antall årsverk for avtalespesialister i Helse Sør-Øst er oppgitt å være 84,49 (7) - det reelle tallet er rundt halvparten.

Svak mobilitet blant nye spesialiteter, slik som i hudfaget, er ikke tatt med i kriteriene for sårbare spesialiteter (5). Og enda viktigere - i rapporten ser man helt bort fra at utdanningssykehusene også har ansvar for å utdanne spesialister til avtalepraksis - ikke bare overlegestillinger. Vi må derfor fastslå at rapporten bygger på grove feil og misvisende premisser hva gjelder vår spesialitet.

\section{Spesialistutdanningen må tilpasses nye tider}

Norsk dermatologi har et distriktsproblem, som vil forsterkes med innføringen av faste utdanningsstillinger. Avdelingslederne kan sørge for en viss gjennomstrømning i utdanningsstillinger på ulike vis, bl.a. med flere permisjoner og tidsbegrensede vikariater. Arbeidsmiljøet kan forsures når noen ikke lenger føler seg velkommen, og uheldige utstøtingsmekanismer kan tre i kraft. Kan oppsigelser bli nødvendig for å oppfylle en avdelings plikt til å utdanne nok hudleger? Hvis ikke noe skjer, kan det bli en propp i utdanningssystemet og et svekket tilbud til pasienter utenfor de store byene.

Vi håper på utspill fra Legeforeningen, Helsedirektoratet og de regionale helseforetakene, særlig Helse Sør-Øst. Spesialistutdanningen må tilpasses en ny tid og en ny generasjon. Man må tenke nytt og annerledes. Fagmiljøene i dermatologi bidrar gjerne til å finne gode løsninger.

\section{Petter Gjersvik}

petter.gjersvik@medisin.uio.no

Daniel de la Rosa Carrillo

$\emptyset y s t e i n$ Grimstad
Petter Gjersvik (f. 1952) er spesialist i hud- og veneriske sykdommer, dr.med., førsteamanuensis ved Institutt for klinisk medisin, Universitetet i Oslo, og leder i Norsk forening for dermatologi og venerologi. Han er medisinsk redaktør i Tidsskriftet.

Forfatter har fylt ut ICMJE-skjemaet og oppgir ingen interessekonflikter.

Daniel de la Rosa Carrillo (f. 1974) er spesialist i hud- og veneriske sykdommer, ph.d., førsteamanuensis ved Universitetet i Oslo og seksjonsleder ved Seksjon for hudsykdommer, Oslo universitetssykehus.

Forfatter har fylt ut ICMJE-skjemaet og oppgir ingen interessekonflikter.

Øystein Grimstad (f. 1972) er spesialist i hudog veneriske sykdommer, ph.d., postdoktor i Helse Nord, førsteamanuensis ved Universitetet i Troms $\varnothing$ - Norges arktiske universitet og leder i spesialitetskomiteen i hud- og veneriske sykdommer.

Forfatter har fylt ut ICMJE-skjemaet og oppgir ingen interessekonflikter.

\section{Litteratur}

1. Den norske legeforening. Oversikt over emnesider for alle spesialiteter. http://legeforeningen.no/ Emner/Spesialiteter/ (9.3.2017).

2. Gjessing $\mathrm{H}$. Faste stillinger. Tidsskr Nor Legeforen 2014; 134: 2007

3. Gjersvik P, Saunes M, Grimstad $\emptyset$. Faste stillinger færre hudleger. Tidsskr Nor Legeforen 2014; 134 2244

4. Lovdata. Fastsettelse av forskrift om spesialistutdanning og spesialistgodkjenning for leger (spe sialistforskriften) og endringer i visse andre forskrifter. https://lovdata.no/dokument/SF/forskrift/ 2016-12-08-1482 (9.3.2017).

5. Leger i primær-og spesialisthelsetjenesten. Rapport 2016. Oslo: Helsedirektoratet, 2016. https://helsedirektoratet.no/Lists/Publikasjoner/ Attachments/1266/IS-2554\%20Leger\%20i\%20 primær-\%20og \%20spesialisthelsetjenesten.pd (9.3.2017).

6. Sundstedt V. Sårbare spesialiteter i fokus. Dagens Medisin 12.1.2017.

7. Legestillingsregisteret. Fordeling av spesialiteten hud- og veneriske sykdommer pr. RHF/HF https://register.helsedirektoratet.no/Lsr/Stilling/ Spesialitet?spesialitet=15 (9.3.2017).

Mottatt 7.2. 2017, første revisjon innsendt 9.3. 2017, godkjent 13.3. 2017. En av forfatterne er redaktør i Tidsskriftet. Manuskriptet er derfor behandlet eksternt av setteredaktør Magne Nylenna.

Publisert først på nett. 